\title{
Experimental analysis of reinforcing columns of reinforced concrete, with anchor steel bolts
}

\section{Análise experimental de reforço de pilares em concreto armado, com chumbadores metálicos}
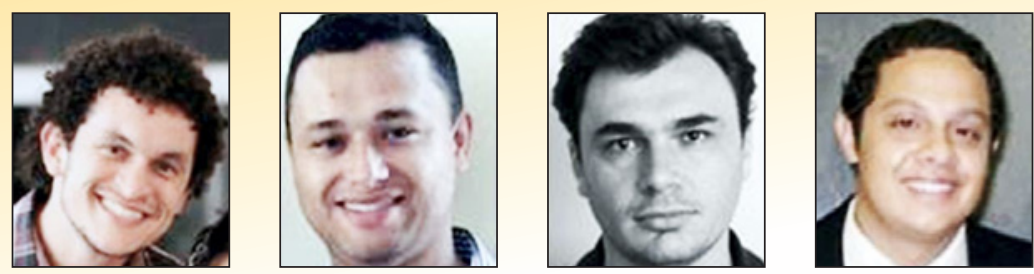

A. C. MESQUITA a adelson@srocha.eng.br

A. S. ROCHA a andersonsrocha@yahoo.com.br

R. G. DELALIBERA ${ }^{b}$ delalibera@ufu.br

W. A. DA SILVA c wellington_andrade@ufu.br

\begin{abstract}
This article presents a columns reinforcement experimental study, with the use of anchor steel bolts and fill with self-compacting concrete. Were tested five columns of reinforced concrete subjected to flexion-compression: two columns were used as reference, and a cross-section equal to $120 \mathrm{x}$ $250 \mathrm{~mm}$; with a monolithic section equal to $155 \times 250 \mathrm{~mm}$ cross section of the same reinforced columns and three which were initially molded with a $120 \times 250 \mathrm{~mm}$ section and subsequently received a layer of $35 \mathrm{~mm}$ thick self-compacting concrete in the compressed side. Despite the studs do not present break, there was peeling of the reinforcement layer. The results indicate the possibility of using this method in reinforcing structural rehabilitation of reinforced concrete columns, with increase in load capacity on average equal to $403 \%$ in relation to the column reference.
\end{abstract}

Keywords: columms, reinforcement, flexo-compression, reiforced concrete, anchor bolts.

\section{Resumo}

Este artigo apresenta um estudo experimental de reforço de pilares, com emprego de chumbadores metálicos e preenchimento com concreto autoadensável. Foram ensaiados cinco pilares de concreto armado submetidos à flexo-compressão: dois pilares foram usados como referência, sendo um com seção transversal igual a $120 \times 250 \mathrm{~mm}$; um monolítico com seção igual a $155 \times 250 \mathrm{~mm}$, mesma seção transversal dos pilares reforçados e três, que inicialmente foram moldados com seção de $120 \times 250 \mathrm{~mm}$ e posteriormente receberam uma camada de $35 \mathrm{~mm}$ de espessura de concreto autoadensável na face comprimida. Apesar dos chumbadores não apresentarem ruptura, houve o desplacamento da camada do reforço. Os resultados obtidos indicam a possibilidade da utilização deste método de reforço na reabilitação estrutural de pilares de concreto armado, apresentando acréscimo na capacidade resistente em média igual a 403 \% em relação ao pilar de referência.

Palavras-chave: pilar, reforço, flexo-compressão, concreto armado, chumbadores.

CMEC, UFG, SRocha Consultoria e Projetos Ltda., Goiânia, GO, Brasil;

Universidade Federal de Uberlândia, Centro de Ciências Exatas e Tecnologia, Faculdade de Engenharia Civil;

Universidade Federal de Goiás, Faculdades de Engenharia, Regional Catalão, Catalão, GO, Brasil.

Received: 22 Oct 2015 • Accepted: 06 May 2016 • Available Online: 23 Sep 2016 


\section{Introduction}

\subsection{Initial considerations}

Columns are linear straight shaft elements, usually arranged vertically where the normal compressive forces are predominant, according to ABNT NBR 6118 [5]. They are intended for sharing external actions to the foundations, although may also transmit to other supporting elements, such as pillars supported transition beams. The active shares on the pillars are generally from the beams and slabs. The pillars are the most important structural elements in the structures, from the point of view of bearing capacity and stability of the building's structural elements, as in the safety aspect. According to Bastos [6], in addition to the transmission of vertical loads to the foundation elements, the pillars are part of the bracing system responsible for ensuring the overall stability of the building. The Federal University of Goiás (UFG), in partnership with the University of Brasilia (UNB), has been developing lines of research on structural reinforcement and Column in reinforced concrete initiated by Adorno [10] followed by Araújo [9] Omar [7] Sahb [1], Melo [12] Birth [8], Marques [3] Ferreira [4] and Virgin [2].

\subsection{Reasons}

The structural rehabilitation area has shown increasing importance

\section{Figure 1 - Reference column shape}

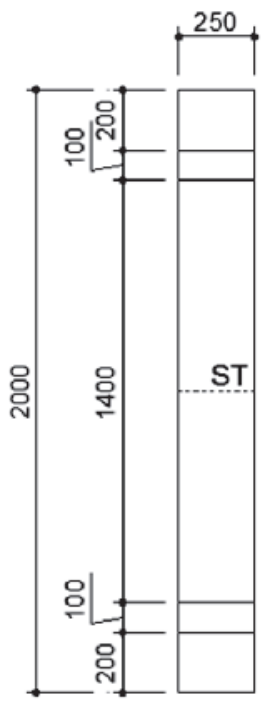

Front View $(\mathrm{mm})$

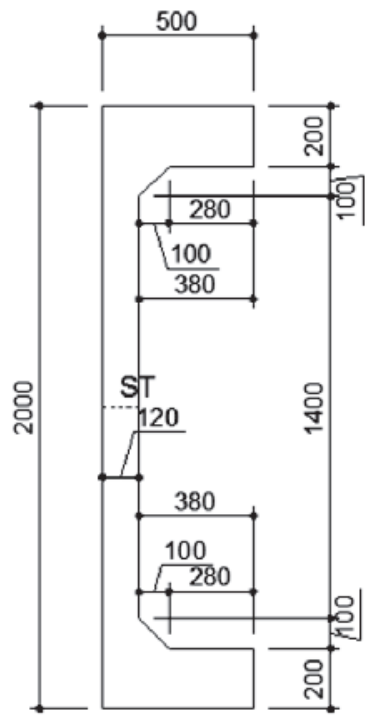

Side View

(mm)

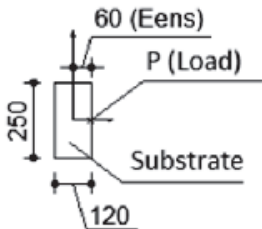

Cross Section

(ST)

Table 1 - Main characteristics of the columns

\begin{tabular}{|c|c|c|c|c|c|c|}
\hline \multicolumn{7}{|c|}{ Main characteristics and nomenclatures of the tested columns } \\
\hline \multicolumn{2}{|c|}{ Nomenclature } & Section $(\mathrm{mm})$ & $\begin{array}{l}\mathrm{N}^{\circ} \text { anchor } \\
\text { bolts }\end{array}$ & $\begin{array}{c}e_{\text {ens }} \\
(\mathrm{mm})\end{array}$ & $\begin{array}{c}\varnothing \text { bolts. } \\
(\mathrm{mm})\end{array}$ & $\begin{array}{c}\Theta_{\mathrm{ref}} \\
(\mathrm{mm})\end{array}$ \\
\hline Referência & $\left(\mathrm{P}_{\mathrm{ref}}\right)$ & $120 \times 250$ & - & 60 & - & - \\
\hline Monolítico & $\left(P_{\text {mon }}\right)$ & $155 \times 250$ & - & 42,5 & - & - \\
\hline P6-150-34-AP150-SP & $\left(P_{1}\right)$ & $155 \times 250$ & 34 & 42,5 & 8 & 35 \\
\hline P6-150-34-AP75-SP & $\left(P_{2}\right)$ & $155 \times 250$ & 34 & 42,5 & 8 & 35 \\
\hline P6-150-34-AP75-CP & $\left(\mathrm{P}_{3}\right)$ & $155 \times 250$ & 34 & 42,5 & 8 & 35 \\
\hline
\end{tabular}


Figure 2 - Monolithic column shape
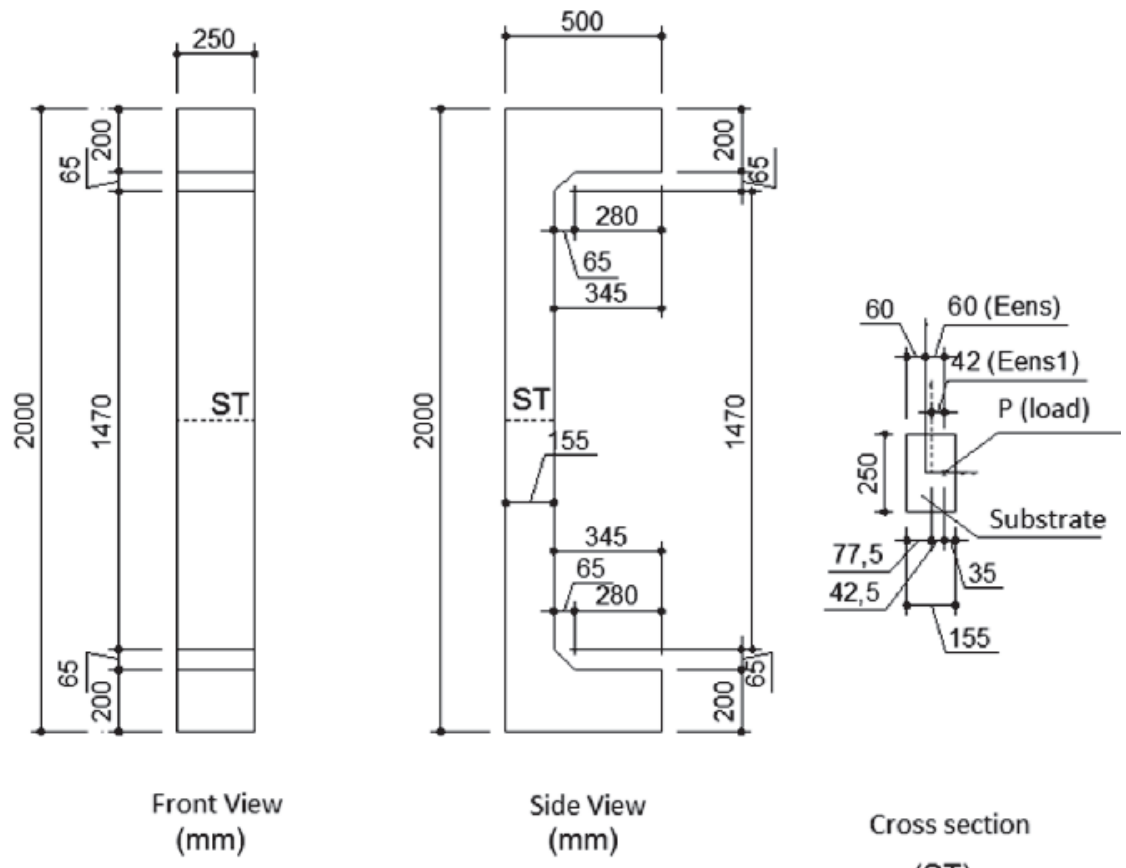

Figure 3 - Shape of reinforcement columns P1, P2 e P3

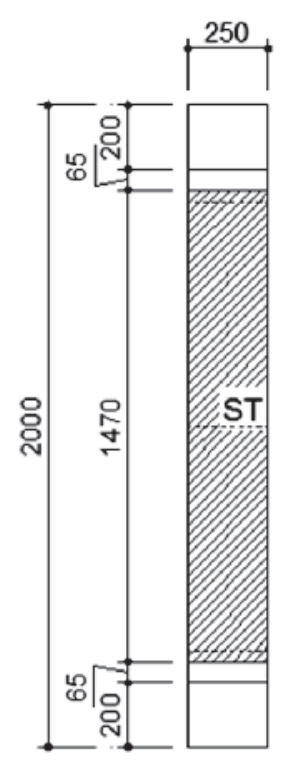

Front View

$(\mathrm{mm})$

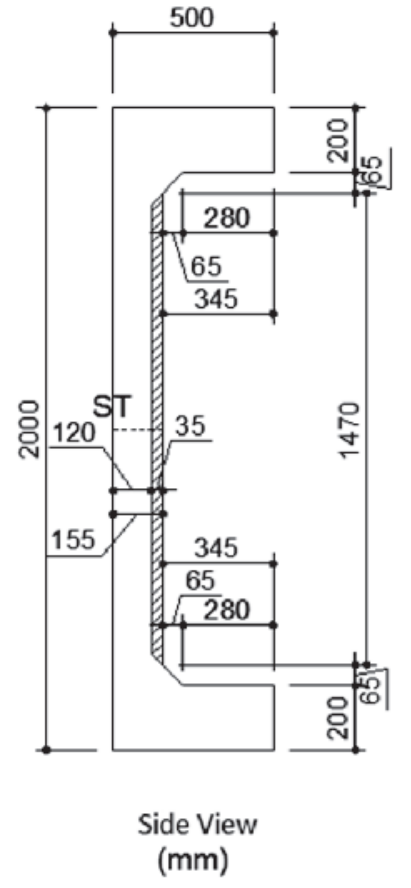

Cross section

(ST) 
in the construction industry, taking into account the need to reduce work time, bolder architectures with large spans and slender buildings, among other reasons. The need to strengthen employment can be applied to structures, correcting pathological building problems or increasing their load bearing capacity. However, even with the development of this branch, the professional structural rehabilitation area still relies primarily on empirical models because there is no specific Brazilian standard for analysis and design of rehabilitated parts. Thus, it is intended to deepen the knowledge of structural reinforced pillars, specifically with metal studs.

\subsection{Objective}

The objective of this study is to analyze the behavior of reinforced pillars after breaking, in order to verify the peeling of the reinforcement.

\section{Experimental program, materials and methods}

\subsection{Geometrical characteristics of the columns}

For this research were built five pillars, being a reference (Pref) with cross section of $120 \times 250 \mathrm{~mm}$ (original section), a monolithic
(PMON) whose cross-section is the same as the reinforced pillars, $155 \times 250 \mathrm{~mm}$, but performed in a single molding and three-reinforced pillars (P1, P2, P3) as described in Table [1].

The geometric characteristics and the armature of the reference column followed dimensional patterns of the pillars Sahb assayed by [1], as shown in Figures [1], [2], [3] and [4]. The positioning and number of bolts have been considered in the same P6-150-34 Virgin pillars [2] indicated in Figures [5], [6] and [7].

The surface of the pillar which received reinforcement was initially prepared by receiving a chiseling by a pressure washer which projects water at high pressure (320 psi); The holes were then run through a drill, control the depth thereof, so that inside the reinforcement of marking executed in the form of pillars before the molding them, it was made a template, so that the same were possible to mark the holes without hitting a stirrup. After cleaning the surface and holes with compressed air, the connectors are positioned and subsequently, are installed in the medium-carrying side as wetting surface. With the above steps ready, the reinforcement frame has been tied to the connectors. The reinforcing molding was carried out with self-compacting concrete (SCC), thickness of $35 \mathrm{~mm}$ with characteristic strength of $30 \mathrm{MPa}$.

\subsection{Concrete substrate}

In the molding of the pillars to be reinforced (substrate) was used

\section{Figure 4 - Frame of reference column (substrate)}

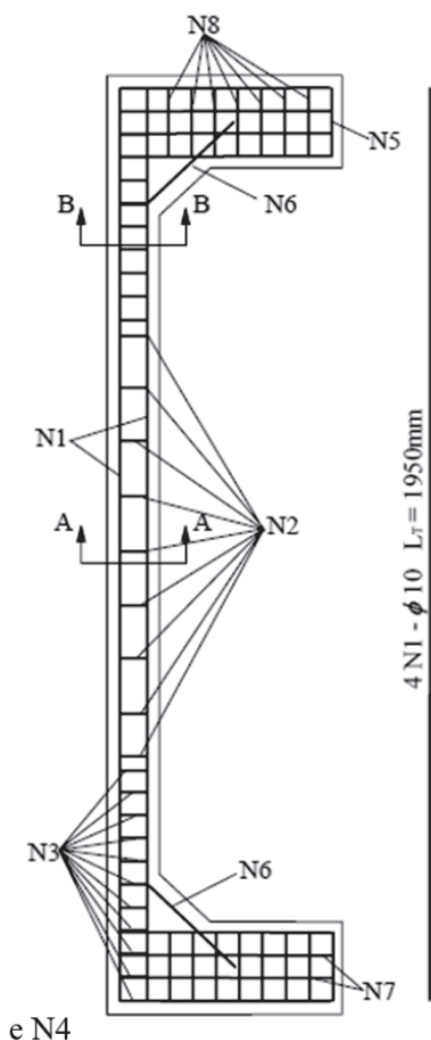

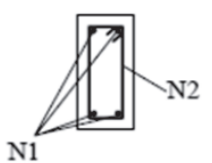

Section A-A

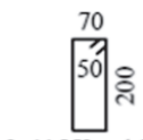

$2 \times 11 \mathrm{~N} 3-\phi 5 \mathrm{c} .50$

$\mathrm{L}_{\mathrm{r}}=640 \mathrm{~mm}$

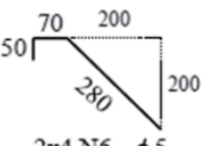

$2 \times 4$ N6- $\phi 5$

$\mathrm{L}_{\mathrm{r}}=550 \mathrm{~mm}$

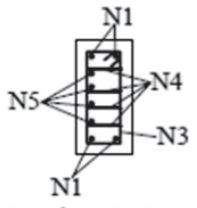

Section B-B
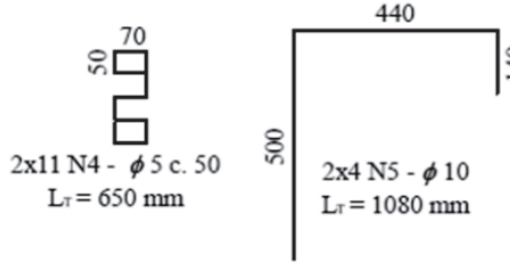

$$
\mathrm{L}_{\mathrm{T}}=650 \mathrm{~mm}
$$

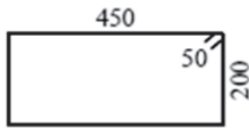

$2 \times 3 \times 7-\phi 5$

$\mathrm{L}_{\mathrm{r}}=1400 \mathrm{~mm}$
$9 \mathrm{~N} 2-\phi 5$ c. 100

$\mathrm{L}_{\mathrm{T}}=640 \mathrm{~mm}$
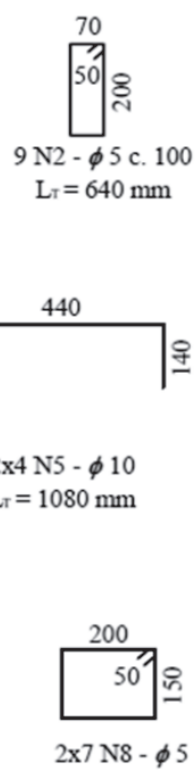

$\mathrm{L}_{\mathrm{T}}=800 \mathrm{~mm}$
Dimensions em millimeters

Fonte: SAHB (2008) 
ready-mix concrete. We used self-compacting concrete (SCC), composed of Portland cement $\left(360 \mathrm{~kg} / \mathrm{m}^{3}\right)$, fine natural sand $(595$ $\left.\mathrm{kg} / \mathrm{m}^{3}\right)$, thick natural sand $\left(175 \mathrm{~kg} / \mathrm{m}^{3}\right)$, crushed stone $0(900 \mathrm{kgf}$ $\left./ \mathrm{m}^{3}\right)$, crushed stone $1\left(110 \mathrm{~kg} / \mathrm{m}^{3}\right)$ water $(180 \mathrm{l} / \mathrm{m})$, multifunction additive $\left(2.7 \mathrm{I} / \mathrm{m}^{3}\right)$ and highplasticiser additives $\left(2 \mathrm{l} / \mathrm{m}^{3}\right)$ dosed to achieve an average compressive strength of $30 \mathrm{MPa}$ at 28 days. The compression strength of the concrete was obtained by two cylindrical specimens with dimensions of $150 \mathrm{~mm}$ height and diameter equal to $300 \mathrm{~mm}$. The values of resistance to compression of the concrete pillar at the time of each test are presented in Table [2].

The tensile strength of the concrete was determined by the two concrete test cylinder with the same dimensions as the previous ones, utilizing the diametric compression test. The lengthwise elastic modulus was also obtained by means of two cylindrical test specimens.
Chose a $30 \mathrm{MPa}$ concrete to get the same resistance adopted by Omar [7] and Sahb [1]. The concrete was produced in central metering.

The average compressive strength of concrete and the tensile substrate, at the time of testing had average values equal to $44.2 \mathrm{MPa}$ and 3.6 MPa, respectively, and the longitudinal elastic modulus Initial was equal to $31.4 \mathrm{GPa}$.

To determine the specific properties of the substrate, both fresh, and hardened, the prescribed procedures were followed in the following standards: NBR 15823 [13], NBR 5738 [14], NBR 5739 [15], NBR 7222 [16], NBR 8522 [17].

\subsection{Reinforcement of concrete}

The strengthening of the pillars of the molding was also done

\section{Figure 5 - Connectors and reinforced column (P1)}
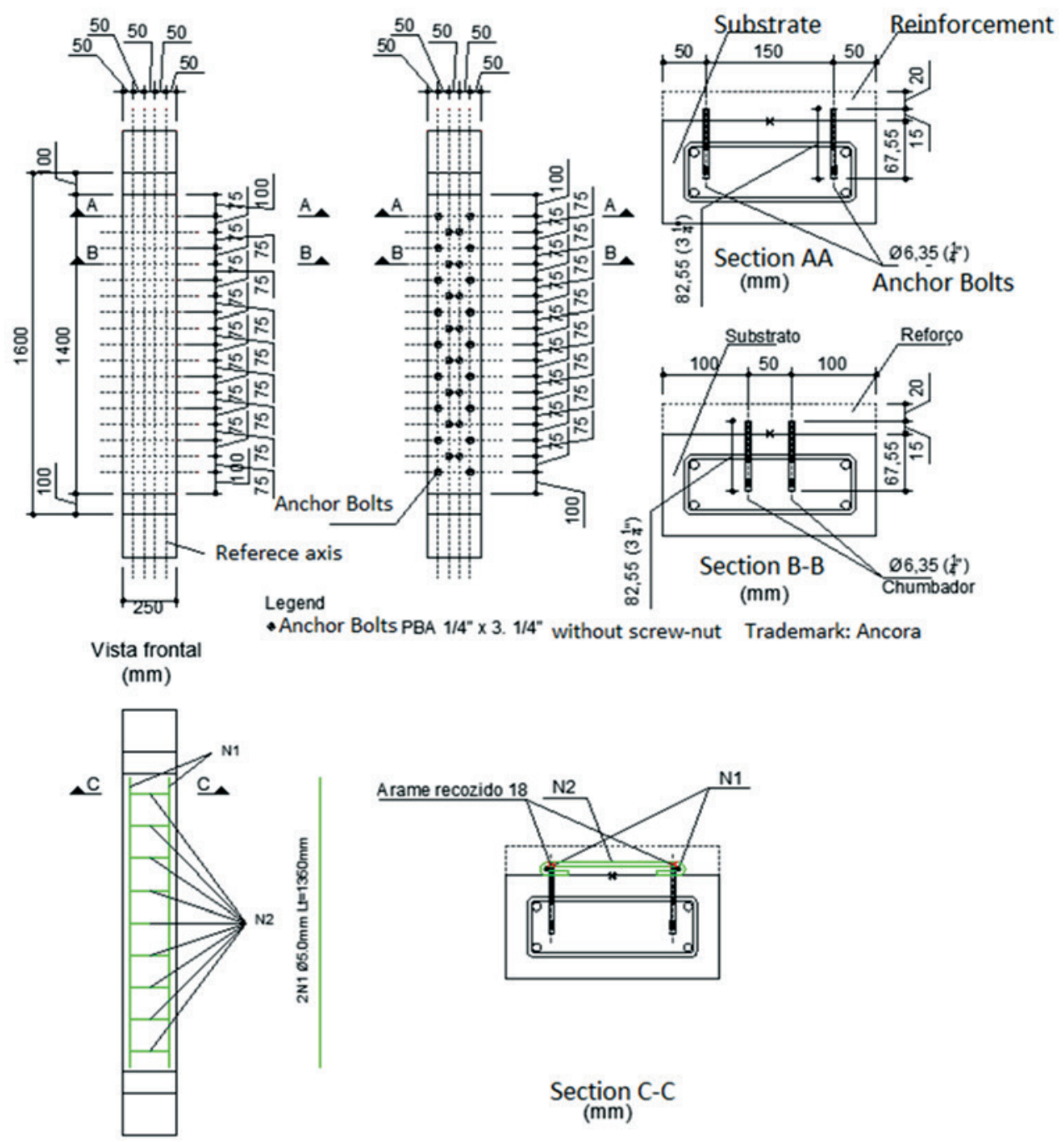

$9 \mathrm{~N} 2$ ø5.0mm o1 $150 \mathrm{Lt}=210 \mathrm{~mm}$

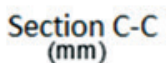


using self-compacting concrete, in order to obtain results similar to the concrete substrate (compressive strength and modulus of elasticity). The same was cast in the laboratory of CMEC structures (Master's Degree in Civil Engineering - UFG). a dosing study was conducted, characterizing and determining the trace materials in mass of concrete used in the reinforcement of the molding which was equal to $1: 2.05 ; 1.36 ; 1.14 ; 0.76: 0.67$ (cement, natural sand, artificial sand, gravel 0,1 crushed stone and water cement ratio - a / c). To achieve the required fluidity and cohesion were also used $0.6 \%$ of multifunction additive, the super plasticizer $0.4 \%$ and $6 \%$ active silica, both in relation to the cement content. For the mechanical properties of the concrete used, they were carried out the same test run to the concrete substrate.

The average compressive strength of concrete and the tensile sub- strate, at the time of testing had average values equal to $39.7 \mathrm{MPa}$ and 3.8 $\mathrm{MPa}$, respectively, and the elastic modulus was equal to $31.2 \mathrm{GPa}$.

\subsection{Steel}

For obtaining the characteristics of the steel used were tested two samples for each diameter $(5.0 \mathrm{~mm}$ and $10.0 \mathrm{~mm})$, using the test to simple traction according to the guidelines of the NBR 6152 [11]. They were determined by averaging the results of the samples the value of the yield stress and the value of each specific strain on the flow of steel bars.

The steel bars of transverse reinforcement and strengthening the equipment with a diameter of $5 \mathrm{~mm}$ showed no well-defined

\section{Figure 6 - Connectors and reinforced column (P2)}

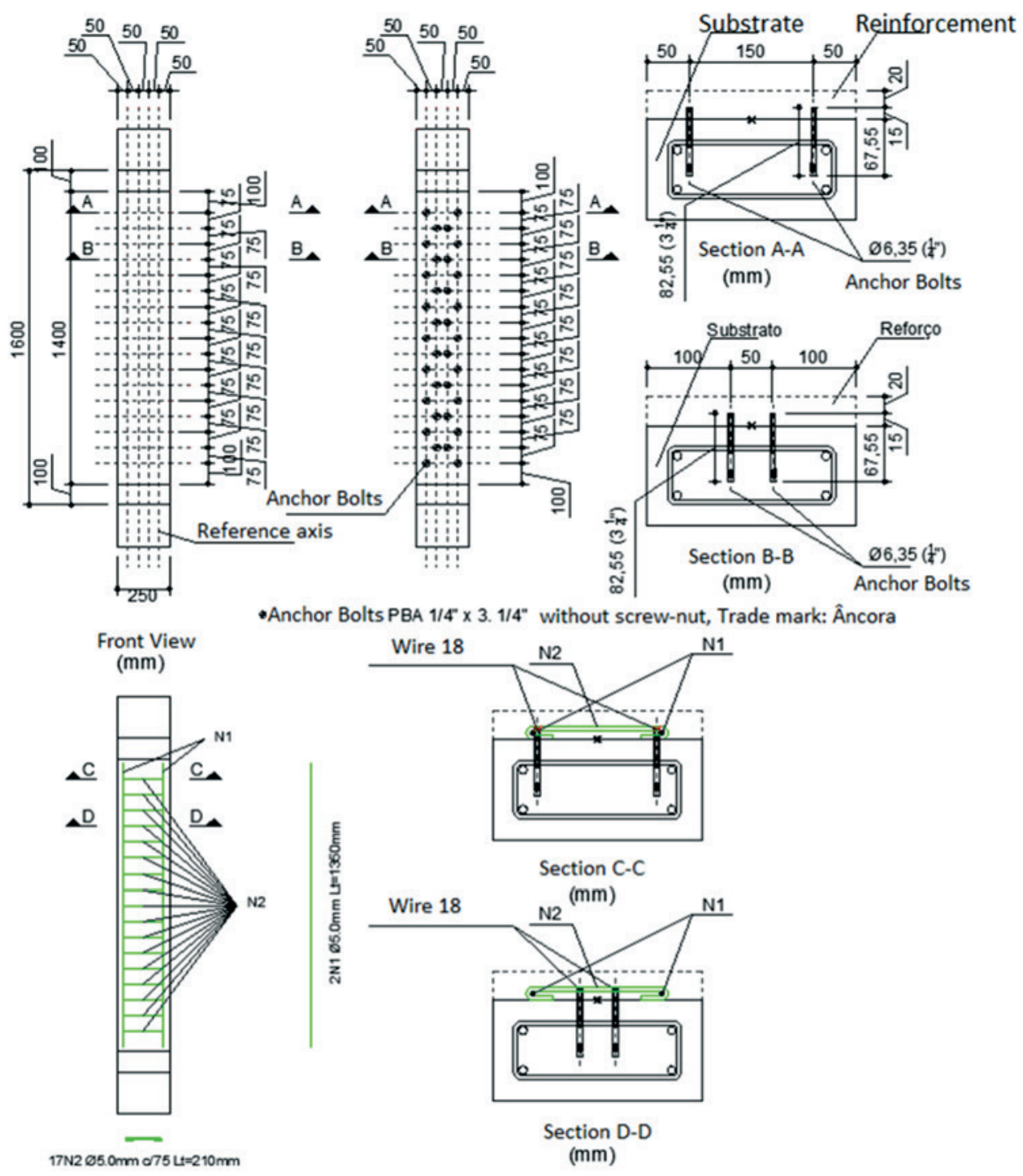


yield level, but we observed a change of direction in the graph stress versus strain, these specimens, thus determining the voltage flow and the specific deformation of the same, since the steel bars of the longitudinal reinforcement with a diameter of $10 \mathrm{~mm}$ were well defined yield level, obtaining the yield stress values and specific deformation equal to $575 \mathrm{MPa}$ and $2.50 \mathrm{~mm}$ / $\mathrm{m}(\%)$ respectively. For armor diameter equal to $5 \mathrm{~mm}$, the results were $720 \mathrm{MPa}$ yield strength and $3.5 \mathrm{~mm} / \mathrm{m}(\%)$ specific deformation, respectively.

\subsection{Steel anchor bolts}

To strengthen concrete weld with the substrate, screws were used bolts type PBA 5/16 "x 31/4" - C / P ANCHOR FIXING SYSTEMS.
With a diameter of $7.9 \mathrm{~mm}(5 / 16$ ") total length of $82.55 \mathrm{~mm} \mathrm{(3} \mathrm{1/4"),}$ average pullout load of $1430 \mathrm{kgf}$, assuming a hole with a minimum depth of $40 \mathrm{~mm}$ and 1 tightening torque $8 \mathrm{kgf} . \mathrm{m}$, according to the manufacturer's technical catalog.

\subsection{Form}

The molding of the substrate of the reference columns and monolithic was performed with the use of metallic molds. The concrete cover $2.5 \mathrm{~cm}$ armor was secured with the use of plastic spacers, properly positioned in the armor. For concrete reinforcement, we used veneered laminated plywood, thickness 18 $\mathrm{mm}$, positioned at the sides of the pillars and fixed by means of metal staples.

\section{Figure 7 - Connectors and reinforcement (P3)}

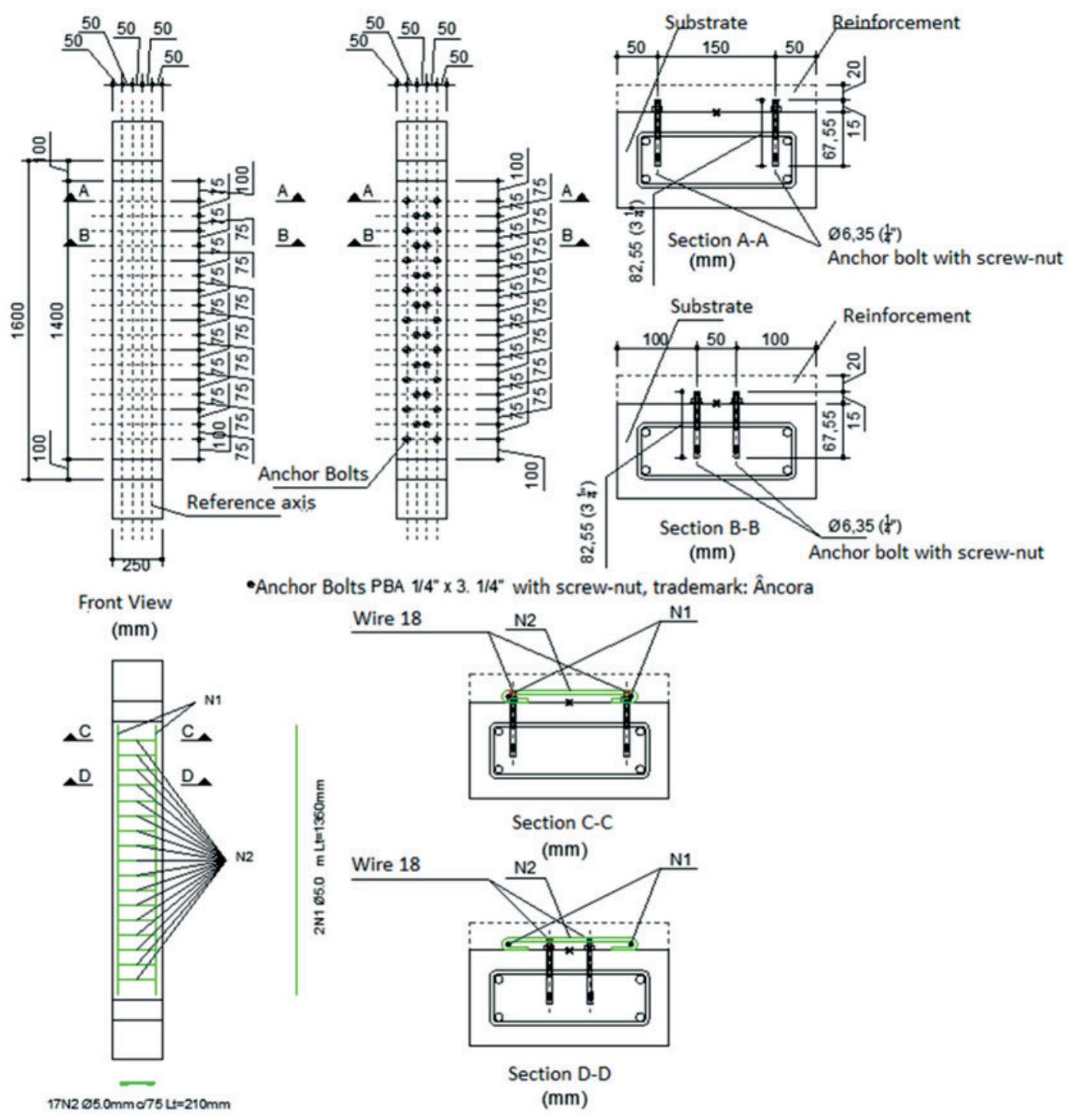


Table 2 - Comparative columns and failure modes

\begin{tabular}{|c|c|c|c|c|c|c|c|c|c|c|c|c|c|}
\hline \multicolumn{14}{|c|}{ General comparative table } \\
\hline \multirow[t]{2}{*}{ Column } & \multicolumn{2}{|c|}{ Age (days) } & \multicolumn{2}{|c|}{$f_{c}(M P a)$} & \multirow{2}{*}{$\begin{array}{l}P_{\text {ult. }} \\
\text { leitura } \\
(\mathrm{kN})\end{array}$} & \multirow[t]{2}{*}{$\underset{(\mathrm{kN})}{\mathrm{P}_{\mathrm{u}}}$} & \multirow{2}{*}{$\begin{array}{l}\mathbf{P}_{\mathrm{u}} / \\
\mathbf{P}_{\text {mon }}\end{array}$} & \multirow[t]{2}{*}{$\begin{array}{l}P_{u} / \\
P_{\text {ref }}\end{array}$} & \multirow{2}{*}{$\begin{array}{c}\text { Desl. } \\
\text { R3 } \\
(\mathrm{mm})\end{array}$} & \multirow{2}{*}{$\begin{array}{l}\text { Desl. } \\
\text { régua } \\
(\mathrm{mm})\end{array}$} & \multirow{2}{*}{$\underset{\varepsilon_{y}}{\varepsilon_{s, \max }}$} & \multirow{2}{*}{$\varepsilon_{\mathrm{s}, \max } /$} & \multirow[t]{2}{*}{ Failure mode } \\
\hline & Sub. & Ref. & Sub. & Ref. & & & & & & & & & \\
\hline$P_{\text {ref }}$ & 90 & - & 41,9 & - & 120,0 & 126,7 & 0,23 & 1,00 & 26,00 & 34,20 & 0,84 & 0,82 & $E A-E C$ \\
\hline$P_{\text {mon }}$ & 80 & - & 41,3 & - & 540,0 & 542,2 & 1,00 & 4,28 & 18,43 & 19,20 & 0,56 & 0,60 & $E A-E C$ \\
\hline $\mathrm{Pl}$ & 192 & 19 & 45,9 & 40,0 & 400,0 & 510,0 & 0,94 & 4,03 & 7,42 & 17,50 & 0,58 & 0,71 & $D R$ \\
\hline P2 & 191 & 18 & 45,9 & 39,4 & 420,0 & 522,0 & 0,96 & 4,12 & 4,63 & 15,00 & 0,60 & 0,61 & DR \\
\hline P3 & 187 & 14 & 45,8 & 26,9 & 500,0 & 501,4 & 0,92 & 3,96 & 11,20 & 17,40 & 0,41 & 0,57 & DR \\
\hline
\end{tabular}

\subsection{Instrumentation}

To measure the deformations of the longitudinal reinforcing steel bars of the substrate and reinforcement of armor, respectively were bonded eight to ten electrical resistance strain gages (EER) of the type PA-06-250BA-120-L and also, four strain gages at the compressed side of the reinforcement such as PA-120-L-06201BA both the EXCEL brand. The reading of the deformations of the gauges was performed by the data collection equipment $A G I-$ LENT BenchLink Data Logger Model $34970^{a}$, Figure [8].

For measuring horizontal and vertical displacements of the pillars nine dial indicators were placed, Mitutoyo brand, with precision of $0.01 \mathrm{~mm}$, named R1 to R9. The clocks were installed with the help

\section{Figure 8 - Instrumentation in models}
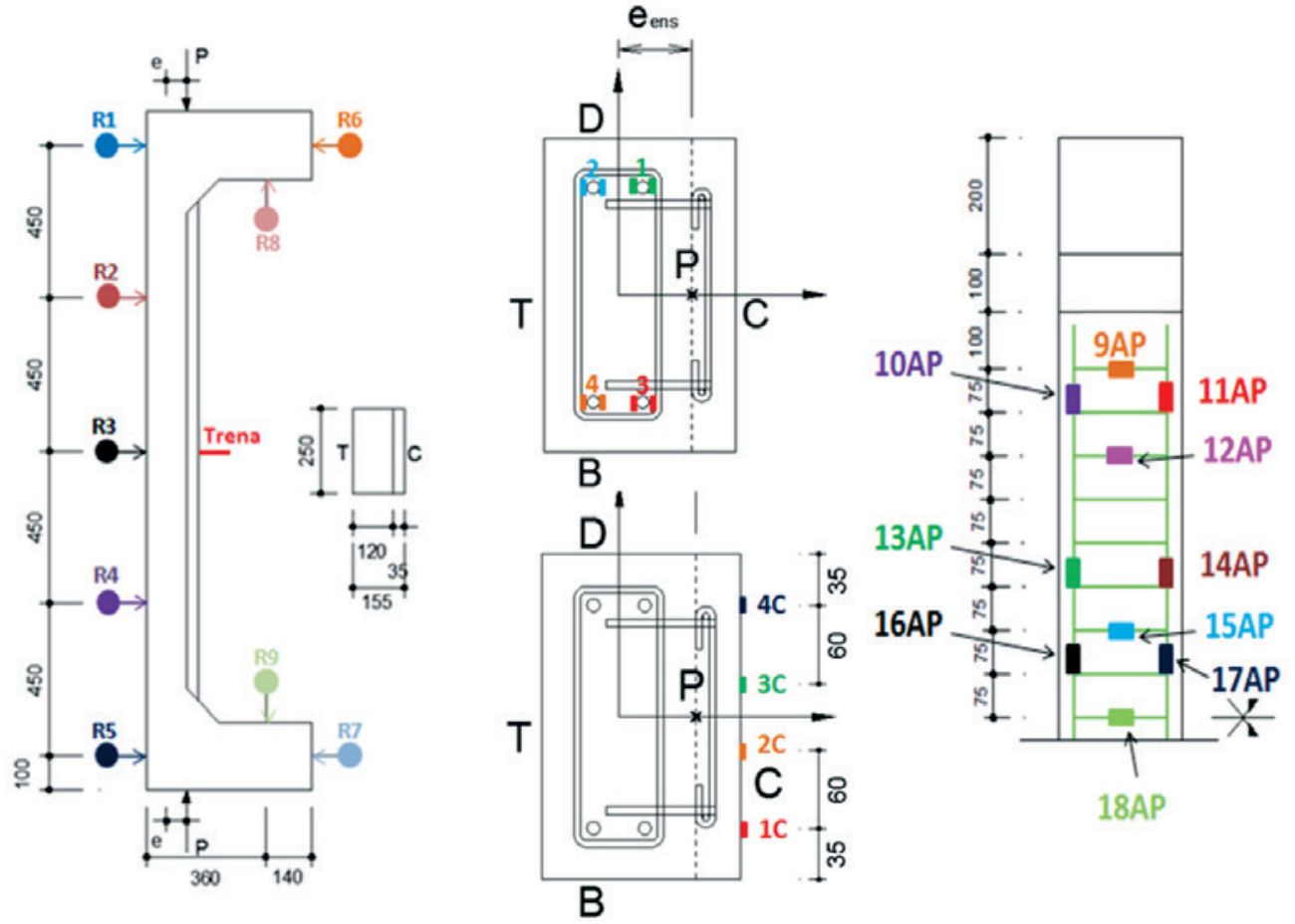
of magnetic base, fixed to a metal support structure and the cursor on metal plates glued on the abutment as the positions shown in the project, Figure [8].

\subsection{Experimental analysis}

The pillars had two meters high and two consoles whose purpose was to allow the load to be applied eccentrically to the central sec- tion. The central section represents the region of interest analysis. The strengthening of the consoles served only to ensure that the rupture occurred in the center section. The tests were performed in the laboratory of the Federal University of Goiás structures. The load was applied by a hydraulic actuator, the Yelow Power brand, with nominal capacity of $1500 \mathrm{kN}$, triggered by a manual hydraulic pump. The hydraulic actuator was positioned at the bottom of the column. To control the applied loading, a load cell with load reading

\section{Figure 9 - Test frame}
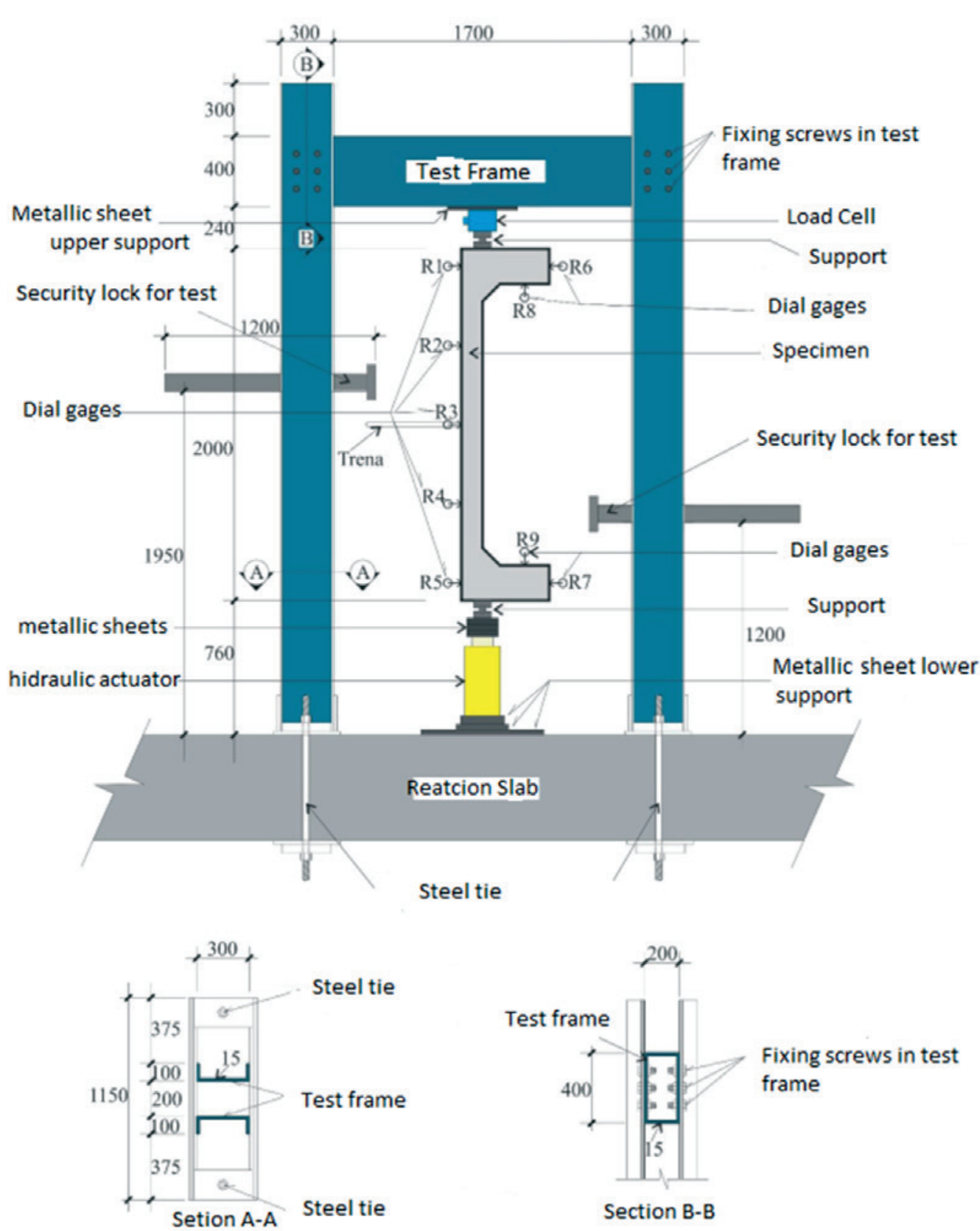
capacity of $1500 \mathrm{kN}$ (Kratos) at the head of the column has been positioned as shown in Figure [9]. The load was applied considering $100 \mathrm{kN}$ load steps, coinciding simultaneously with the reading of all instruments.

\section{Results and discussions}

All reinforced pillars obtained the last force larger than that the abutment reference $(P)$ and near of the load monolithic pillar (PMON), but still being smaller.

The resistive load expected of the models studied, was defined based on the analysis in several similar previous studies and also depending on the results of numerical analysis of the same.

It has been found that the use of the reinforcement armature little influence on the behavior of the models studied, and also did not prevent the peeling of the reinforcement of concrete. All pillars had rupture of the sudden kind, caused by strengthening peeling.

Unlike the compressive strength of the concrete substrate and the reinforcement of concrete, the pillar P1 was $5.9 \mathrm{MPa}, \mathrm{P} 2, \mathrm{P} 36.5$ $\mathrm{MPa}$ and $18.9 \mathrm{MPa}$.

The reinforced pillars had a higher breaking load values as from 3.96 to 4.28 times the reference load of the pillar, as shown in Table [2]. The pillars reached on average $94 \%$ load of the monolithic pillar. On Table [2] there is a comparative analysis of all the pillars, with the concrete characteristics, last strength, larger displacement, greater deformation and failure modes.

It was observed that there was the appearance of various cracks in reinforced pillars, but it was not possible to check a critical crack that could lead to rupture according of the loading increasing.

\section{Figure 10 - Curve Load vs. Displacement, for dial gage R3}
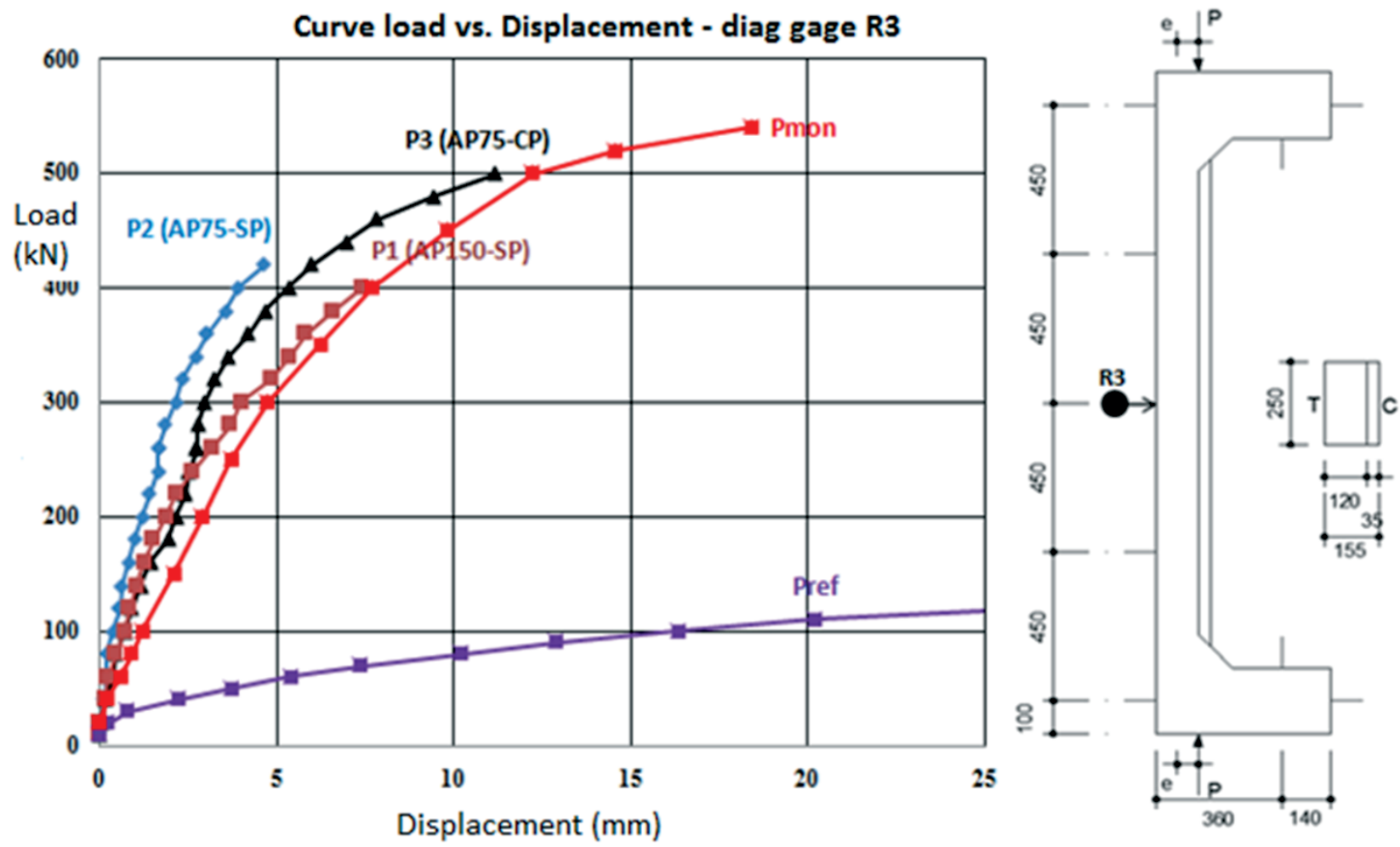

\begin{tabular}{|c|c|c|c|c|c|}
\cline { 2 - 6 } \multicolumn{1}{c|}{} & P1 & P2 & P3 & Pref & Pmon \\
\hline Pu (kN) & 510 & 522 & 501,4 & 126,7 & 542,2 \\
\hline $\begin{array}{c}\text { Pret,rel } \\
\text { (kN) }\end{array}$ & 400 & 420 & 500 & 120 & 540 \\
\hline e (mm) & 42,5 & 42,5 & 42,5 & 60 & 42,5 \\
\hline $\begin{array}{c}\text { fc sub. } \\
\text { (MPa) }\end{array}$ & 45,9 & 45,9 & 45,8 & 41,9 & 41,3 \\
\hline $\begin{array}{c}\text { fc ref. } \\
\text { (MPa) }\end{array}$ & 40 & 39,4 & 26,9 & - & - \\
\hline
\end{tabular}


That's because one of the pillars was rupture in the upper region, one in the central region and in the region below the surface studied, occurring shortly after the peeling of the reinforcement.

Before the reinforcement layer peeling, the pillars had a behavior similar to the monolithic pillar, both displacements, as shown in Figure [10], as the deformations. They showed a tendency to flow and crushing of concrete steel, Figures [11] and [12] characteristic of ductile rupture, but the enhancement of peeling caused a sharp break in the models. Since the reference columns and monolithic had a smooth breakage, featuring a relatively ductile and gradual breakage.

The dial gauges were removed before the rupture of the pillars to be undamaged. After removal of the dial indicators reading the shifts in R3 clock position, continued to be made by monitoring the naked eye, through the displacement of a measuring tape with millimeter scale, properly secured to the pillar. The largest displace- ments were verified by measuring tape and the dial indicator R3, positioned in the central region of the $\mathrm{T}$ face of the pillars.

Figure [11] shows the greatest deformation of the tensioned reinforcement (face T). Figure [13] shows the deformation of the reinforcement of the reinforcement bars in the most compressed region (face $\mathrm{C}$ ). The steel bars with a diameter of $10 \mathrm{~mm}$ (longitudinal reinforcement substrate) and $5 \mathrm{~mm}$ (reinforcing armature), were properly characterized and obtained a flow beginning of deformation (Ey) $2.5 \%$ and $3.5 \%$, respectively.

The limit for the crushing of the concrete was adopted as indicated in ISO 6118 [5], $3.5 \%$, considering the case of flexible pressing.

\section{Conclusion}

The last strength of the pillars $\mathrm{P} 1, \mathrm{P} 2$ and $\mathrm{P} 3$ were on average from

\section{Figure 11 - Curve Load vs. Strain - Steel bar more tensile}

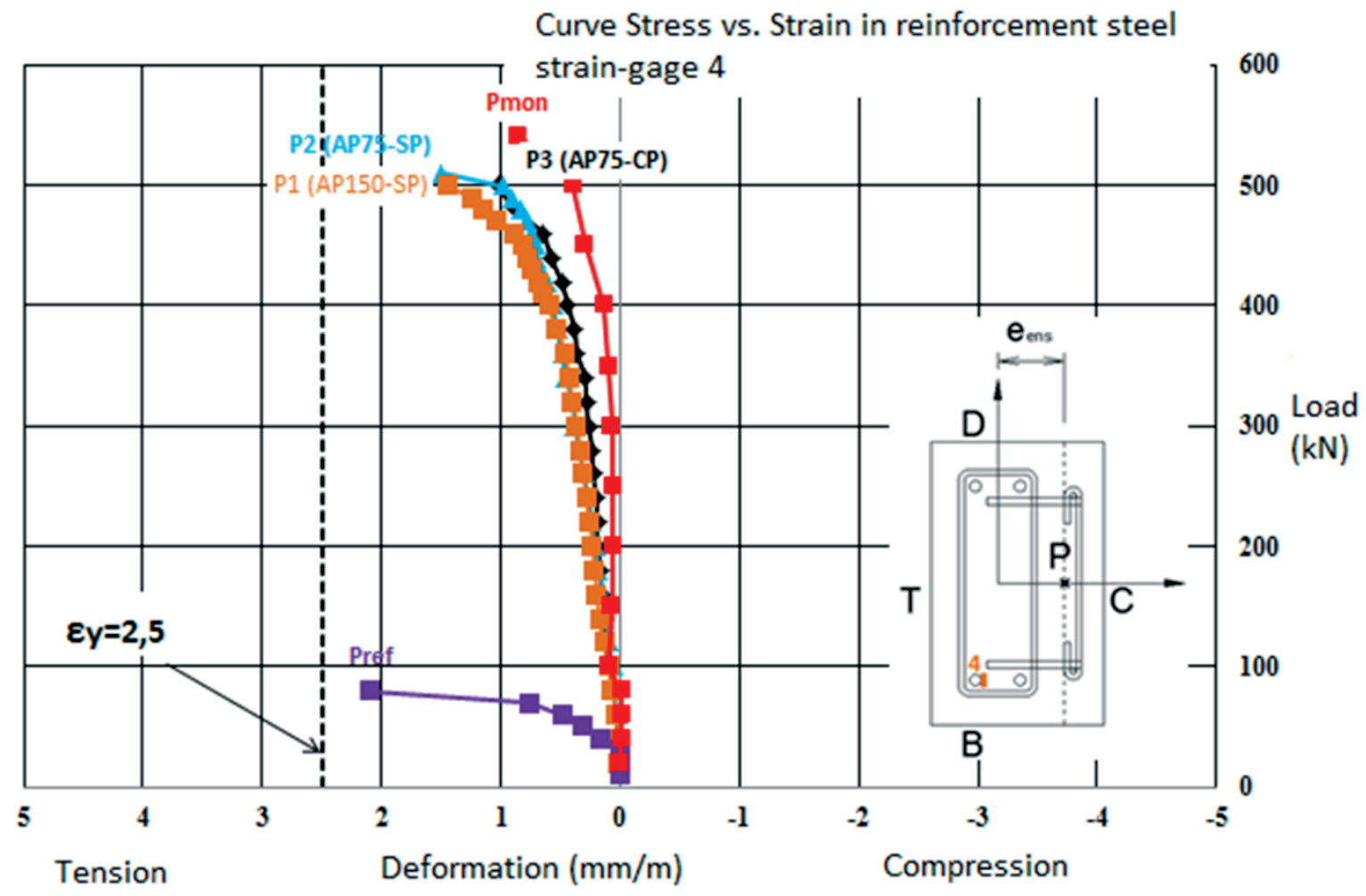

\begin{tabular}{|c|c|c|c|c|c|}
\cline { 2 - 6 } \multicolumn{1}{c|}{} & P1 & P2 & P3 & Pref & Pmon \\
\hline Pu (kN) & 510 & 522 & 501,4 & 126,7 & 542,2 \\
\hline $\begin{array}{c}\text { Pret, rel } \\
\text { (kN) }\end{array}$ & 400 & 420 & 500 & 120 & 540 \\
\hline e (mm) & 42,5 & 42,5 & 42,5 & 60 & 42,5 \\
\hline $\begin{array}{c}\text { fc sub. } \\
\text { (MPa) }\end{array}$ & 45,9 & 45,9 & 45,8 & 41,9 & 41,3 \\
\hline $\begin{array}{c}\text { fc ref. } \\
\text { (MPa) }\end{array}$ & 40 & 39,4 & 26,9 & - & - \\
\hline
\end{tabular}




\section{Figure 12 - Curve Load vs. Strain - concrete Column, side more compressed}

Curve Load vs. Strain - concrete

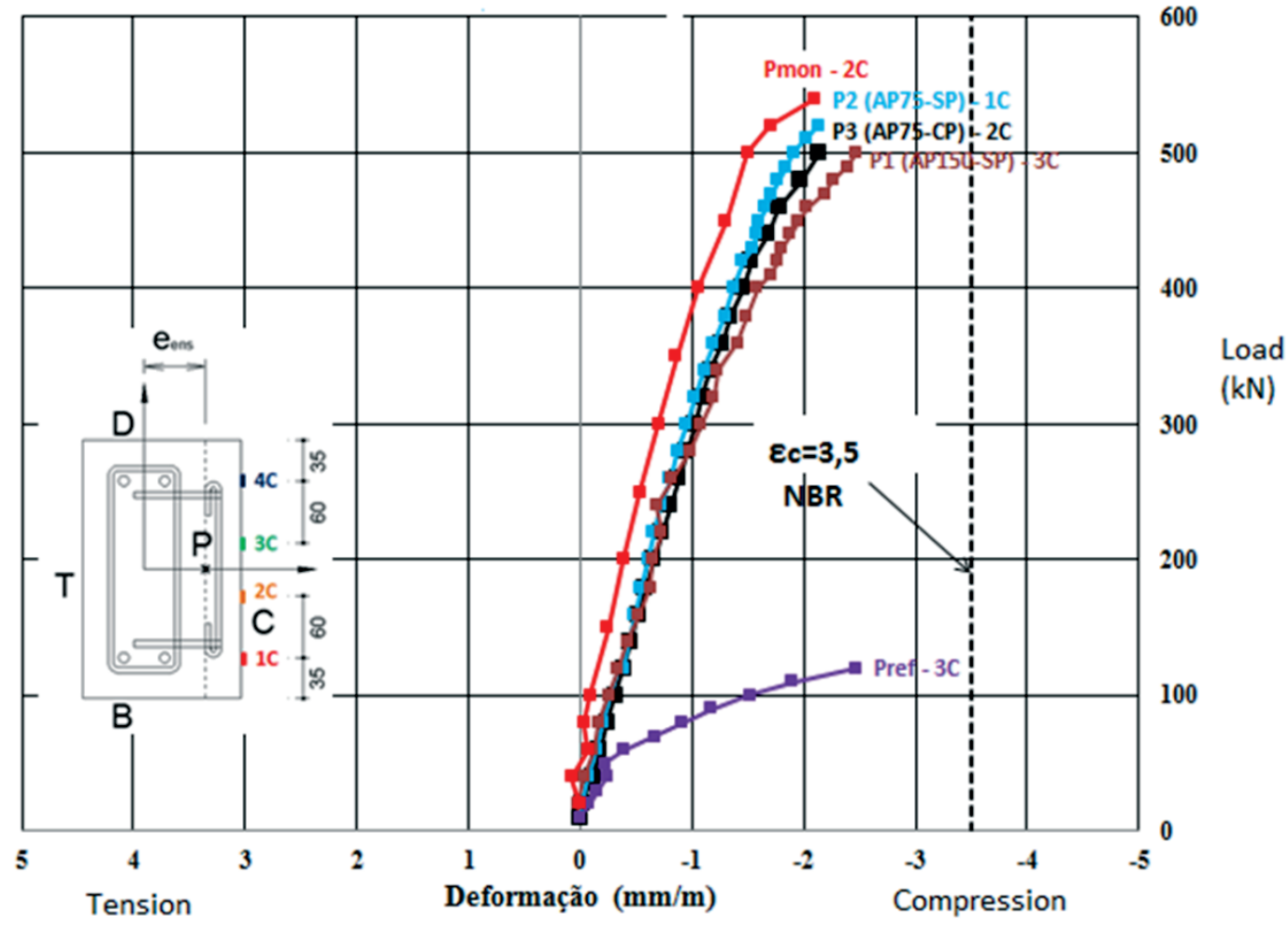

3.96 to 4.28 times greater than the final column of the reference power and an average $94 \%$ load monolithic pillar employee confirming the enhancement of the efficiency and highlighting possibility of using this type of reinforcement in structural rehabilitation, considering certain safety factor, in order to prevent the peeling of the reinforcement layer.

The displacements and deformations observed on the pillars $\mathrm{P} 1$, $\mathrm{P} 2$ and $\mathrm{P} 3$ were close to the monolithic pillar, but there was peeling of the reinforcement layer, causing a sharp break.

The variation in the spacing of the reinforcement of armor, had little influence in the breaking loads and displacements of the studied pillars. In none of the studied pillars was rupture of the anchor bolts.

So that the strengthening technique applied can be used in real situations. However, it is necessary the use of safety factors and a thorough detailed analysis of the part to be rehabilitated. And then show a proper sizing model that will avoid peeling and follow normative policies.

\section{Acknowledgements}

On the Coordination of Higher Education Personnel Improvement - CAPES for financial support in the form of the first author. To Redimix Concrete Brazil S.A. for the supply of materials for molding the concrete used. Mr. Divine Pedro Rocha for the transport of materials characterization. The Laboratory Carlos Campos Con- sultoria e Projetos Ltda for the characterization of materials, concrete dosing study and availability of equipment and hand labor for professional pressure washer operation. At PUC-GO by steel bars tensile testing.

\section{Referências bibliográficas}

[1] SAHB, K. F. P. Análise Experimental de Pilares de Concreto Armado Submetidos à Flexo-Compressão, Reforçados com Concreto Auto Adensável e Chumbadores. 224f. Dissertação (Mestrado), UFG, Goiânia, Goiás, 2008.

[2] VIRGENS, P. J. Análise experimental de pilares de concreto armado, com carga excêntrica, reforçados com chumbadores e concreto auto adensável (caa), REEC - Revista Eletrônica de Engenharia Civil, volume 8, n 1, Goiânia, Goiás, 2014.

[3] MARQUES, M. G. Análise do comportamento de pilares de concreto armado reforçados com chumbadores e concreto auto adensável. 197f. Dissertação (Mestrado), UFG, Goiânia, Goiás, 2014.

[4] FERREIRA, D. B.. Análise experimental de pilares de concreto armado reforçados com concreto auto adensável e conectores. 199f. Dissertação (Mestrado), UFG, Goiânia, Goiás, 2014.

[5] ABNT NBR 6118: Projeto de estruturas de concreto - Procedimento. Rio de Janeiro, 2014. 
[6] BASTOS, P. S. d. S., Fundamentos do Concreto Armado, Bauru, São Paulo (UNESP), 2004, 107P. Notas de Aula.

[7] OMAR, Mohamad Y.M. Análise experimental de pilares de concreto armado reforçados com concreto auto adensável (CAA). Dissertação (Mestrado) - Universidade Federal de Goiás, Goiânia, 2006.

[8] NASCIMENTO, P. P. Análise experimental de pilares de concreto armado submetidos à flexo-compressão, reforçados com concreto auto adensável e conectores. 205f. Dissertação (Mestrado), UFG, Goiânia, Goiás, 2009.

[9] ARAÚJO, L. M. B. Análise teórico experimental de pilares de concreto armado submetidos à flexão normal composta. 196f. Dissertação (Mestrado), UFG, Goiânia, 2004.

[10] ADORNO, A. L. C. Análise Teórica e Experimental de Pilares em Concreto Simples e Armado sob Flexo-Compressão
Reta. 399p. Tese (Doutorado) - Departamento de Engenharia Civil e Ambiental/UnB, Brasília, DF, 2004.

[11] ABNT NBR 6152: Metais metálicos - Determinação das propriedades mecânicas à tração, Rio de Janeiro, 2002.

[12] MELO, C. E. L. Análise Experimental e Numérica de Pilares Birrotulados de Concreto Armado Submetidos a FlexoCompressão Normal. Tese (Doutorado) - Departamento de Engenharia Civil e Ambiental/UnB, Brasília, DF, 2009.

[13] ABNT NBR 15823: Concreto auto-adensável, Rio de Janeiro, 2010.

[14] ABNT NBR 5738: Concreto - Procedimento para Moldagem e Cura de Corpos-de-prova, Rio de Janeiro, 2007.

[15] ABNT NBR 5739: Concreto - Ensaios de compressão de Corpos-de-prova Cilíndricos, Rio de Janeiro, 2007.

[16] ABNT NBR 7222: Concreto e argamassa - Determinação da

\section{Figure 13 - Curve Load vs. Strain - concrete column, comparison between strain-gage 16AP and 13AP}

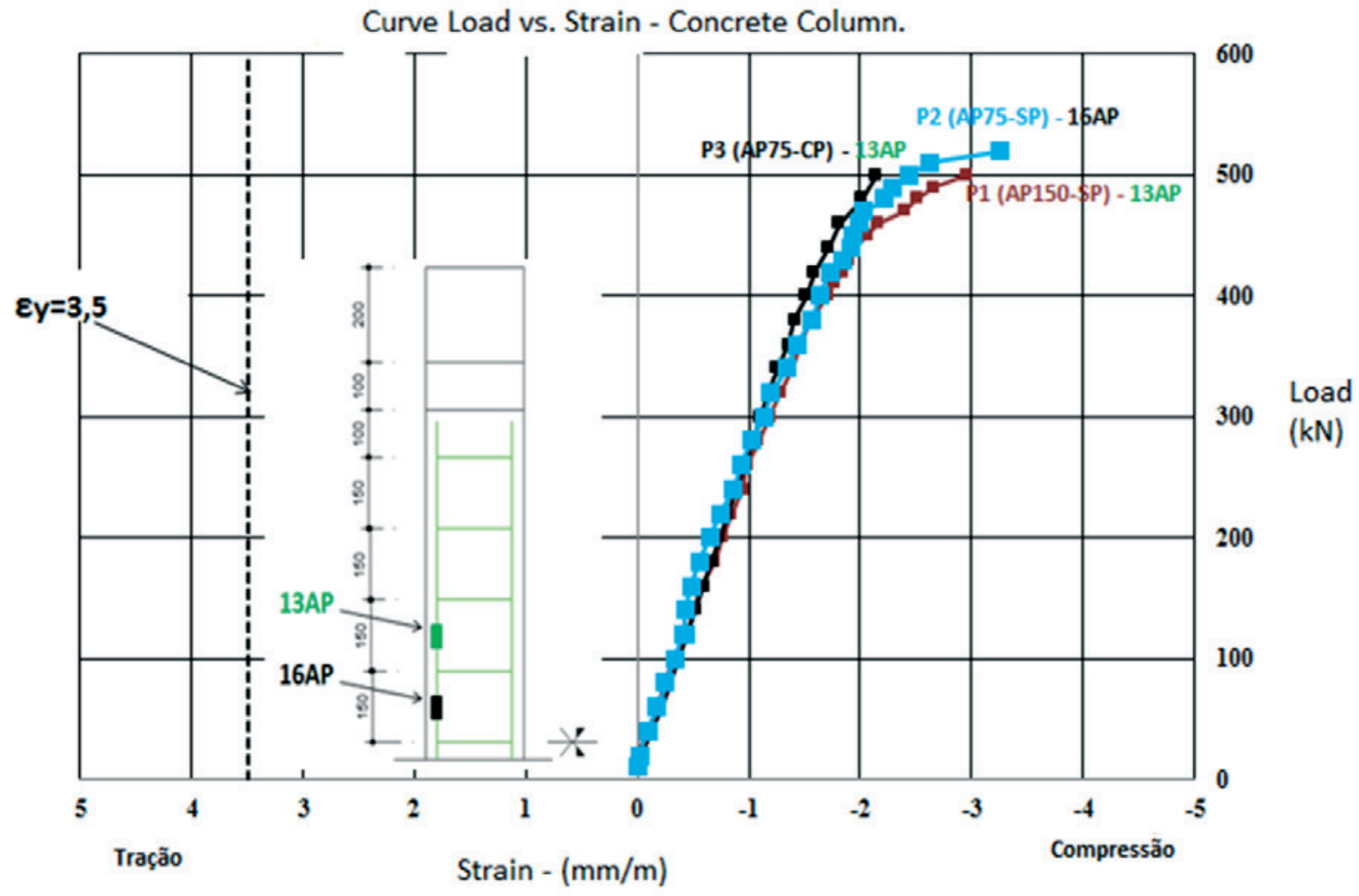

\begin{tabular}{|c|c|c|c|c|c|}
\cline { 2 - 6 } \multicolumn{1}{c|}{} & P1 & P2 & P3 & Pref & Pmon \\
\hline Pu (kN) & 510 & 522 & 501,4 & 126,7 & 542,2 \\
\hline $\begin{array}{c}\text { Pret,rel } \\
\text { (kN) }\end{array}$ & 400 & 420 & 500 & 120 & 540 \\
\hline e (mm) & 42,5 & 42,5 & 42,5 & 60 & 42,5 \\
\hline $\begin{array}{c}\text { fc sub. } \\
\text { (MPa) }\end{array}$ & 45,9 & 45,9 & 45,8 & 41,9 & 41,3 \\
\hline $\begin{array}{c}\text { fc ref. } \\
\text { (MPa) }\end{array}$ & 40 & 39,4 & 26,9 & - & - \\
\hline
\end{tabular}


resistência à tração por compressão diametral de Corposde-prova Cilíndricos, Rio de Janeiro, 2011.

[17] ABNT NBR 8522: Concreto - Determinação do módulo estático de elasticidade à compressão, Rio de Janeiro, 2008. 